\title{
The Legality of Executive Order No. 6, 2018 on Asset Recovery in Nigeria
}

\author{
Oyelowo Oyewo \\ Professor of Law, Head of Department of Public Law, Faculty of Law, University of Lagos, Nigeria
}

\begin{abstract}
The conceptual nature and usage of executive orders in the exercise of presidential or executive powers, especially with regard to Presidential Executive Order No. 6 of 2018, is discussed as a prelude to the consideration of the salient features of Executive Order 6 of 2018, and analysis of the constitutionality and legality of Order No. 6 of 2018, before finally, postulating on the possible impact of the Order on government's efforts aimed at asset-tracing and recovery from proceeds of crime.

Keywords: executive order, corruption, anti-corruption, asset tracing and recovery, constitutionality and legality
\end{abstract} DOI: $10.7176 / \mathrm{JLPG} / 81-01$

\subsection{Introduction}

Recently, the President of the Federal Republic of Nigeria, issued the Executive Order No. 6 of 2018, on preservation of proceeds of crime and asset recovery. Obviously, the Administration of President Muhammadu Buhari is not the first democratically-elected President to issue Executive Orders, as former Presidents, such as, Shehu Shagari and Olusegun Obasanjo issued such Orders. In 1980, then President Shagari issued an Executive Order to modify the Public Order Act (this was unsuccessfully challenged in court by then Governors of Ogun and Borno States). ${ }^{1}$ In 1999, then President Obasanjo issued Executive Orders to abolish the Petroleum Trust Fund (PTF) and to proclaim May 29 as Democracy Day. ${ }^{2}$ Interestingly, the preamble to the Executive Order 6 of 2018 offers glimpses into its raison d'être ${ }^{3}$ - "an anticorruption instrument to be used to secure corruptly acquired public assets from being dubiously dissipated."

However, many have queried the necessity for, and legality of the Executive Order No. 6 of 2018, due to the existence of enormous powers of anti-corruption agencies vested in them by the enabling laws of the anticorruption legal framework, ${ }^{5}$ such as Economic and Financial Crimes Commission (EFCC) Act, the Money Laundering Act (MLA), the Independent Corrupt Practices Commission (ICPC) Act, and Administration of Criminal Justice Act (ACJA), among other. ${ }^{6}$ Indeed, criticisms have trailed the Executive Order No. 6 of 2018, on several grounds, including: its violation of the doctrine of separation of powers, rule of law, and constitutionally guaranteed fundamental rights, both in substance and its application. ${ }^{7}$ Moreover, it has been argued that the fundamental rights provisions in Chapter IV of the Constitution in sections 33-44, and the African Charter on Human and Peoples' Rights constitute shield for the right of the citizens and a limitation on overarching powers of the Nigerian government, even in waging war against corruption. ${ }^{8}$ However, qualification

\footnotetext{
${ }^{1}$ A.G, Ogun State v. A.G, Federation (1982) LPELR-SC.53/1981 (Consolidated); (1982) 1-2 S.C. (Reprint) 7

${ }^{2}$ Another example of an executive order is the one on local content in public procurement which was made pursuant to the Public Procurement Act 2007 on fulfilment of domestic preference. Others include the executive order on local content and the one on budget process.

3 "Whereas it is the responsibility of the Federal Government of Nigeria to protect the resources of Nigeria from all forms of Corruption; Whereas Corruption constitutes an unusual and extraordinary threat to the well-being, national security and stability of the country's political and economic systems, as well as its continuous existence; and must be effectively addressed;"

${ }^{4}$ Corruption is often perceived as a "Nigerian Factor". "Nigerian Factor" is the acronym for the practice of bribery and corruption based on the general perception that every public official has a "price" at which he/she may be "bought". It also translates into the general belief that public office/public service is for personal enrichment and accumulation of wealth, as part of every Nigerians share of the "national cake" for himself/herself and for his/her family, tribe/ethnic group. See J.P. Oliver de Sardan "A Moral Economy of Corruption in Africa?", (1999) 37 Journal of Modern African Studies 25 - 55. See also Ngozi Okonjo-Iweala, Fighting Corruption is Dangerous: The Story Behind the Headlines, (2018, The MIT Press, Cambridge) 27-104

${ }^{5}$ International Instruments: United Nations Convention Against Corruption (UNCAC) of 2005; African Union Convention on Preventing and Combating Corruption and Related Offences (AU Convention) of 2003; Economic Community of West African Protocol on the Fight Against Corruption (ECOWAS Protocol) of 2001; United Nations Convention Against Transnational Organised Crime (UNTOC) of 2003. Domestic Legislation: The Constitution of the Federal Republic of Nigeria, 1999: The Criminal Code Act, 1961; Penal Code Law, 1959; Corrupt Practices and Other Related Offences Act, 2003; Economic and Financial Crimes (Establishment) Act, 2004; Money Laundering (Prohibition) Act, 2004

${ }^{6}$ EFCC Act Cap E1, LFN 2004, section 6 (d) - (f), 7(2). Section 34 (1) of the EFCC Act 2004 empowers the Commission to freeze any account suspected of being used for financial crimes.

${ }^{7}$ As stated in Esai Dangabar v. FRN (2012) LPELR-19732 (CA), the EFCC can only freeze our accounts based on the order of a court. In Umezulike v. Chairman, EFCC (2017) LPELR-43454(CA) Ogunwumiju JCA further stated that:

It is my humble view that in whatever circumstances, whether it is a matter involving criminal prosecution under the EFCC Act or not, an order of attachment of property can be set aside, quashed or vacated where there is proof that there has been suppression of material facts or misrepresentation of facts or where the Court which made the order had no jurisdiction to make the order.

${ }^{8}$ See B.O. Nwabueze, The Presidential Constitution of Nigeria (1982), 250. See Uzoukwu vs. Ezeonu ii (1991) 6 NWLR (PT 200) 708 at
} 
of the guaranteed rights, together with derogations and claw-back clauses clearly demonstrate that the guaranteed rights are not absolute. ${ }^{1}$ Indeed, the Administration of Criminal Justice Act 2015 in Parts 33 and 34 dealt with the judicial processes requisite for the custody, disposal of property and seizure, forfeiture, confiscation and destruction of instrumentality of crime. Interestingly, the Economic and Financial Crimes Commission Act, the Money Laundering Act, among other anti-corruption statutes, already empower the executive and its anticorruption agencies, particularly, to freeze, attach, confiscate and forfeit the property of persons reasonably suspected of commission of crimes/offences under their enabling statutes. ${ }^{2}$

In this paper, the conceptual nature and usage of Executive Orders in the exercise of presidential or executive powers, especially with regard to Presidential Executive Order No. 6 of 2018, will first be examined. Second, a discussion of the salient features of Executive Order 6 of 2018 will be considered. Third, an analysis of the constitutionality and legality of the Order will be undertaken, particularly, in the light of decided cases. Finally, the possible impact of the Order on government efforts aimed at asset tracing, and recovery from proceeds of crime will be offered.

\subsection{Executive Orders: Definition and Nature}

Historically, Executive Orders were first used in the United States of America (US) by President George Washington on June 8, 1789, (addressed to the heads of the federal departments, instructing them "to impress me with a full, precise, and distinct general idea of the affairs of the United States" in their fields), but truly took on a new role under President Franklin D. Roosevelt, who issued over 3,000 of them. Most recently, while President Obama rarely called it into use, President Trump has resorted to the usage of Executive Orders to address several issues, but the challenge of the constitutionality of these Orders have been unsuccessful till date. ${ }^{3}$

Executive Orders refer to written directives or instructions which a President or State Governor may give the executive branch of government in order to give effect to governmental policies or enforce the law of the land. These instructions are used to direct the actions of government officials and agencies, and may sometimes affect the legal rights and responsibilities of private parties. ${ }^{4}$ Executive orders have also been defined as commands "... directly given by the president to an executive agency, class of persons or body under the executive arm of government." 5

The nature of executive orders has been subject of much debate with different views as to whether it constitutes law or not. Cian Murphy while commenting on the Custers \& Others case, ${ }^{6}$ stated that according to the European Court of Human Rights (ECtHR), in order to determine whether an Executive Order amounts to Law, the court must consider whether the order had 'sufficient legal basis in domestic law'. ${ }^{7}$ For instance under section 315 of the CFRN, where the president is given powers to modify existing laws and bring them in conformity with the constitution, a constitutional basis exists for the executive to engage in some form of quasilegislation. In $A$-G Abia State v. A-G Federation, ${ }^{8}$ the Supreme Court held thus:

It is noteworthy that the Constitution, itself, has defined "appropriate authority" for the purpose of an Act of National Assembly for modification as the "President." It also defines

761; Essien vs. Inyang \& ors (2011) LPELR- CA/C/103/2008; Ransome-Kuti vs. Attorney-General of the Federation (1985) 7 NWLR (PT 6) 211 at 229 - 231. - Now, fundamental rights are rights which stand above the ordinary laws of the land. They are in fact antecedent to the political society itself. Fundamental rights which have been described as the minimum living standard for civilized humanity have their origin dating back to the Magna Carta, the Royal Charter of political rights given to rebellious English Barons by King John on June 19, 1215. The fundamental rights have been enshrined in the Constitution so that the rights could be inalienable and immutable to the extent of the non-immutability of the Constitution itself.

${ }^{1}$ Section 45 of the 1999 Constitution. See Mbanefo v.Molokwu (2014) 1-2 S.C. (Pt. II) 137; [2014] LOR (14/2/2014) SC. See Governing Council of NTI, Kaduna v. NASU (2018) LPELR-44557(CA). cf. The Punch Nigeria Ltd. V Attorney General of the Federation (1998) 1 HRLRA 488. See Abacha v Fawehinmi (2001) 51 WRN 29

${ }^{2}$ Dame Mrs. Patience Ibifaka Jonathan vs Federal Republic of Nigeria LER [2018] CA/L/578/2017; Umezulike v. Chairman EFCC [2017] LPELR-43454(CA); Felimon Enterprises Limited v. Chairman, E.F.C.C. [2013] LPELR-20366(CA), at 18-19. cf. Suit Nos. FHC/ABJ/CS/14/2017- In the Matter of an Application by the Chairman of Economic and Financial Crimes Commission and In The Applications of SNEPCO and NAE, delivered on delivered on Friday 17 March 2017; Rana Industries v. EFCC (FHC/LCS/715/2015

${ }^{3}$ Executive Orders 101: What are they and how do Presidents use them? Constitution Daily, National Constitution Center, January 17, 2017, available at: https://constitutioncenter.org/blog/executive-orders-101-what-are-they-and-how-do-presidents-use-them/

${ }^{4}$ See Bradley, Curtis and Posner, Eric A., Presidential Signing Statements and Executive Power (July 2006). University of Chicago, Public Law Working Paper No. 133; Duke Law School Legal Studies Paper No. 121 at p.43. Available at SSRN: https://ssrn.com/abstract=922400 or http://dx.doi.org/10.2139/ssrn.922400 (noting that it is "one of many tools that the president has at his disposal for controlling the executive branch.”)

${ }^{5}$ Okebukola and Kana, "Executive Orders in Nigeria as Valid Legislative Instruments and Administrative Tools." NAUJILJ Vol. 3 (2012) at p.61. See also Hedge, David M., "The George W. Bush Presidency and Political Control of the Bureaucracy" (2009). APSA 2009 Toronto Meeting Paper at p.17. Available at SSRN: https://ssrn.com/abstract=1450715 (noting that Executive Orders are used to "assert presidential authority" and are "treated as having the something like the force of law." (sic))

${ }^{6}$ Custers, Deveaux and Turk v. Denmark Judgment 3 May 2007, para 84.

${ }^{7}$ Murphy, Cian C., "The Principle of Legality in Criminal Law Under the ECHR" (November 16, 2009). European Human Rights Law Review, Vol. 2, p. 192, 2010. Available at SSRN: https://ssrn.com/abstract=1513623 (noting that the legality of the order was upheld by the court)

${ }^{8}$ supra note 2, per Belgore, J.S.C. (Pp.26-27, paras. F-C) 
"modification" as follows in s. 315(4) (c):"315(4)(c) 'modification' includes addition, alteration, omission or repeal. Thus, the President has wide power when modifying any existing law to bring it in conformity with the Constitution. It is true that "separation of powers" is essential to a healthy democracy, the power given the President and also to State Governors in existing law of the State by the Constitution is not an abuse of the principle or doctrine of separation of powers, it is essential to giving meaning to an existing law so that the Constitution itself is not abused.

Therefore, it follows that an executive order could amount to law where there are constitutional or statutory provisions giving the president powers to make pronouncements or such modifications to existing laws as to bring it in consonance with the constitution.

Another way to look at this is through an abridged version of the command theory as put forward by John Austin. It is agreed that the President has executive powers vested in him by the CFRN in order to give effect to laws pursuant to section 5, then any command or directive given to members of the executive arm made pursuant thereto would have the force of law, as they would not be in a position to choose to obey such directives or not. Generally, the powers of the President or a State Governor to direct the affairs of the executive arm of government usually derive from a constitution or a federal or state law. In essence, there must be a constitutional or statutory basis for the issuance of executive orders.

\subsection{The Presidential Executive Order No. 6 (2018): Putting things in Perspective}

Putting the foregoing into context, the Presidential Executive Order No. 6, 2018 is targeted at Government officials (former and current), ${ }^{1}$ persons acting on their behalf, politically exposed persons, or any person directly or indirectly engaged in corrupt practices. The mischief that the Order seeks to address is, to prevent the dissipation of funds suspected to be proceeds of such crimes until the final determination of by a court through the use of all lawful and statutory means. This would include obtaining interim forfeiture orders from the courts and administrative confiscation pending the obtaining of such orders. The following are some significant provisions of the Presidential Executive Order:

- Section 1 (a)- protection of assets from dissipation by employing all available lawful or statutory means, including seeking the appropriate Order(s) of Court where necessary, and shall not be transferred, withdrawn or dealt with in any way until the final determination by a court of competent jurisdiction of any corruption related matter against such a person. And made applicable in particular to those connected with persons listed in First Schedule to the Order, (or any such list as may be issued by the Attorney General of the Federation)

- Section 1(b)- made applicable to government officials and/or persons acting on their behalf engages in corrupt practices or money laundering of illicit activities, to be liable in addition to forfeiting the proceeds, to be subject to disciplinary procedure in accordance with Public Service Rules and investigation by the Code of Conduct Bureau

- Section 1(c) - this gives powers to the Attorney General of the Federation (AGF) to coordinate law enforcement agencies with regard to asset preservation actions and also mandating him/her to publish a list of all Assets protected pursuant to the Order from time to time. Also, enforcement agencies are to give information regarding investigations of entities or persons suspected to have engaged in corrupt acts, to the AGF when he requests for it.

- Section 2 - this section provides that persons or entities who generally pervert the course of justice shall be prosecuted in line with the provision of any Law(s) governing unlawful acts.

- Section 3 - this section encourages persons who allege infringement of rights by virtue of this order, to seek redress in a competent court.

- Section 4 - this section directs enforcement agencies to diligently collaborate with the Federal Ministry of Justice to ensure the preservation of suspicious assets.

- Section 5 (b) (i) - this section places corrupt activities involving funds or assets in the sum or value in excess of fifty million Naira (N50,000,000) or its equivalent in foreign currency, within the purview of the Executive Order and thereby subject to monitoring by the AGF's office.

- First Schedule - List cases to be immediately affected by the Executive Order

- Second Schedule - Agencies of the federal government of Nigeria affected by the Order.

It must be noted that the Executive Order states clearly that appropriate order(s) of court where necessary

\footnotetext{
${ }^{1}$ The President explained that he relied on Section 5 of the 1999 Constitution (as amended), which empowers the President to execute and maintain the provisions of the Constitution, as well as all laws made by the National Assembly. The Executive Order also restrains owners of assets under investigation from carrying out any further transaction on such assets. Also, the President has mandated the Attorney General of the Federation and Minister of Justice, Abubakar Malami, to publish from time to time, a list of all assets protected pursuant to the Order among other provisions in the proclamation. See "The President's Executive Order 6" in The Sun of 13" July 2018, available at: https://sunnewsonline.com/president-executive-order-6/
} 
must be sought in furtherance of exercise of powers thereunder. ${ }^{1}$ Furthermore, it evinces a clear strategy as to how corruption matters, especially those bordering on Asset Recovery and Preservation, are to be handled. It gives the Attorney General of the Federation the power to coordinate the implementation of the order while adhering to applicable laws which means that it is not meant to be implemented arbitrarily. ${ }^{2}$ More importantly, it focuses primarily on corruption cases already instituted before courts of competent jurisdiction as enumerated in First Schedule and directed at federal agencies as listed in the Second Schedule.

\subsection{Constitutionality and legality of the Use of Executive Orders in Nigeria}

The doctrine of Separation of Powers dictates that the three arms of government, i.e. the legislature, executive and judiciary, possess and exercise varying and distinct powers. This is to avoid the concentration of all the powers of government in one arm of government, guard against dictatorial rule, and to ensure checks and balances. $^{3}$ Thus, in the Constitution of the Federal Republic of Nigeria 1999 (CFRN), the doctrine is entrenched by virtue of sections 4,5 and 6 which cover legislative, executive and judicial powers respectively. ${ }^{4}$ This has received judicial approval in a plethora of cases. ${ }^{5}$ In Adeyemi \& Ors v. AG Oyo State \& Ors (1984), ${ }^{6}$ the Supreme Court held as follows:

"The doctrine of separation of powers means that neither the legislature, the executive, nor the judiciary should exercise the whole or part of another's power. It was held by this court in Lakanmi \& Anor. v The Attorney-General of Western State \& Ors. (1974) 4 E.C.S.L.R. 713 at p.731; (1971) 1 U.I.L.R. 201 at p.218 that the structure of the Constitution of the Federation of Nigeria, 1963, (hereinafter referred to as lithe 1963 Constitution") as suspended and modified by the Constitution (Suspension and Modification) Act, 1966 (No. 1 of 1966) was based on the separation of powers; and in the distribution of powers amongst the organs of government the courts were vested with the exclusive right to determine justiciable controversies between citizens and between citizens and the State". ${ }^{7}$

There have been concerns as to how the various arms of government can be compelled to adhere to the doctrine of separation of powers while bearing in mind the need for checks and balances. This writer had cause to comment on this as follows:

However, a complete separation of powers in the sense of a division of the three functions of government amongst the three arms with no overlapping or interrelationship (i.e. complete compartmentalisation of powers), even if theoretically feasible, will not be practically viable as it will make governmental powers inoperable and bring the government to a standstill. Hence, a corollary to the doctrine of separation of powers is the principle of "checks and balances, ${ }^{8}$

The corollary principle of checks and balances has evolved into the counterpoise for the balancing of powers between arms of governments in the exercise of governmental powers. Whereby the executive can be interloped in a chain of exercise of powers by the legislature and vice versa. Indeed, the practice of delegation of powers has further blurred the distinctive boundaries in the separation of powers. Albeit, the courts have been recognised in the primary role of maintaining the distinctive separation through the doctrine of constitutional judicial review. ${ }^{9}$ Hence, the role of the court in determining the constitutionality of the Executive Order No. 6 2018 , and legality of actions taken pursuant thereto is central to the theme under discussion.

Although, there are no express constitutional or statutory provisions on Executive Orders, however, when

\footnotetext{
${ }^{1}$ Such existing laws as the EFCC Act, ICPC Act, Money Laundering Act, inter alia, grant power to the anti-corruption agencies to secure assets freezing orders from the courts pre-conviction.

${ }^{2}$ Section $1(\mathrm{c})$ of the Order.

${ }^{3}$ KM Mowoe, Constitutional Law in Nigeria (2008, Multhouse Press Ltd., Lagos) 23-33

${ }^{4}$ Attorney-General of Abia State \& Ors v. Attorney-General of the Federation (2003) LPELR-610(SC) per Belgore, J.S.C. (P.22, paras.C-G) ${ }^{5}$ A.G. Abia State v. A.G. Federation (2002) 6 NWLR (Pt. 763) 265 at 397; A. G. Abia State \& 2 Ors. v. A.G. Federation \& Ors. (2006) 7 SCNJ 1; Ugba v Suswan [2014] 14 NWLR (Pt. 1427) 264; Kabiawu v Thompson [2014] LPELR-23258-(CA); Kayode v. The Governor of Kwara State (2005) 18 NWLR (Pt. 957) 324 at 352; A. G. Lagos State v. A. G. Federation (2004) 20 NSCQLR 99; Michael Daramola (2003) 5 S.C. 70: Hon. Abdullahi Maccido Ahmed v. Sokoto State House of Assembly \& Anor. (2002) 44 WRN 52; Governor of Lagos State v Ojukwu (1986) 1 NWLR (Pt 18) 621; A.G. Ogun State v. A.G. Federation (1982) 3 NCLR 166; A.G. Bendel State v A.G. Federation [1982]3 NCLR 1. See Oyelowo Oyewo, Modern Administrative Law and Practice (2016 University of Lagos Press, Lagos) 49-56

${ }^{6}$ His Highness Lamidi Olayiwola Adeyemi (Alafin of Oyo) \& Ors v. A-G., Oyo State \& Ors (1984) LPELR-169(SC)

${ }^{7}$ Per Uwais, J.S.C pp. 165-166, paras. G-D. See also Chevron Nigeria Limited v. Imo State House of Assembly \& Ors (2016) LPELR41563(CA); John Kadiya v. Solomon Daushep Lar \& Ors (1983) LPELR-1643(SC); Olusegun Adebayo Oni \& Anor v. Dr. John Olukayode Fayemi \& Ors (2013) LPELR-20671(SC); see also Oyelowo Oyewo, Modern Administrative Law \& Practice in Nigeria, (supra) at p.49 where I noted that:

The non-fusion of the functions of government in one person or body of persons, i.e. the separation of exercise of the law-making or legislative powers by the legislature, the law implementation or executive powers by the executive, and the interpretation or adjudicative powers by the courts or independent judiciary, has become the kernel of the doctrine of separation of powers. ${ }^{8}$ Oyewo, ibid at p.49-50

${ }^{9}$ A.G. Lagos State v A.G. Federation [2004) 18 NWLR (Pt. 904) 1: INEC v Musa (2003) 3 NWLR (Pt. 806) 72; A.G. Abia v A.G. Federation (2002) 4 NWLR (Pt. 763) 264;
} 
one considers the relevant provisions of the Constitution of the Federal Republic of Nigeria 1999 (As Amended) (hereinafter "CFRN"), on the powers of the executive a constitutional basis for executive Orders is revealed. To this end, section 5(1) CFRN provides as follows.

Subject to the provisions of this Constitution, the executive powers of the Federation:

(a) shall be vested in the President and may subject as aforesaid and to the provisions of any law made by the National Assembly, be exercised by him either directly or through the VicePresident and Ministers of the Government of the Federation or officers in the public service of the Federation; and

(b) shall extend to the execution and maintenance of this Constitution, all laws made by the National Assembly and to all matters with respect to which the National Assembly has, for the time being, power to make laws. ${ }^{1}$

This provision vests the executive powers of the Federation in the President. However, it does not specify how these powers may be enforced or exercised, thereby giving the President ample discretion to justify the use of Executive Orders. ${ }^{2}$

The vesting of executive powers in the President by the CFRN lends credence to the theory of the "Unitary Executive," as put forward by President George W. Bush of the USA, in which all executive and administrative powers of the national government are focused in the President. ${ }^{3}$

Section 5 of the CFRN, which vests executive powers in the President, is however subject to the rest of the provisions of the constitution and to any provisions of any law made by the National Assembly. ${ }^{4}$ The National Assembly has made no law relating to Executive Orders, and by necessary implication, the President is justified to make use of them in the exercise of his executive powers.

With regards to other provisions of the CFRN, section 15(5) is relevant especially with regard to corruption. The section provides that "the state shall abolish all corrupt practices and abuse of power." More so, the concept of "abuse of power" relates mostly to public officers or members of the executive arm of government. Not surprising, the stated constitutional basis for making Executive Order 6 is founded on sections 5 and 15(5) of the 1999 Constitution, against the unstated background of the interpretation of the Supreme Court in A.G. Ondov A.G. Federation ${ }^{5}$ and the cases developed on the that locus classicus. ${ }^{6}$ Mention must be made of section 13 of the Constitution that makes it "duty and responsibility of all organs of government, and of all authorities and persons, exercising legislative, executive or judicial powers, to conform to, observe and apply the provisions of this Chapter of this Constitution."

The Courts have had cause to pronounce on the dangers of corruption and the importance of the fight against corruption. ${ }^{7}$ In the case of Altimate Inv. Ltd v. Castle \& Cubicles Ltd, the Court of Appeal held as follows:

...it is important to mention that this is a time when the Nigerian nation is fighting the difficult battle against corruption in all its ramification. All hands should be on deck to eliminate or eradicate this social ill. Corruption or corrupt practices, if not cheked (sic), threaten the peace, order and good government. Uwais CJN (as he then was) in Attorney-General, Ondo State v. Attorney-General, Federation (2002) FWLR (Pt. 111) 1972) at 2070-2071, (2002) 9 NWLR (Pt. 772) 222 at 306 said: 'Corruption is not a disease which afflicts public officers alone but society as a whole. If it is therefore to be eradicated effectively, the solution to it must be pervasive to cover every segment of the society.' Mohammed JSC at page 2106 FWLR or page 347-348 of NWLR said: 'It is quite plain that the issue of corruption in the Nigerian society has gone beyond our borders. It is no more a local affair. It is a national malaise which must be tackled by the government of the Federal Republic. The disastrous consequences of the evil practice of corruption has (sic) taken this nation into the list of the most corrupt nations on earth...' Ogwuegbu JSC at page 2098 of FWLR or pages 337-339 of NWLR referred to the preamble of Chief Afe Babalola SAN in his brief in the appeal where he said: 'It is a notorious fact that one of the ills which have plagued and are still plaguing the Nigerian nation is corruption in all facets of our national life. It is an incontrovertible fact that the present economic, morals and or quagmire in

\footnotetext{
${ }^{1}$ See section 5(2) CFRN for similar provisions with respect to State Governments.

${ }^{2}$ A.G, Ogun State v. A.G, Federation (1982) LPELR-SC.53/1981 (Consolidated); (1982) 1-2 S.C. (Reprint) 7

${ }^{3}$ Manheim, Karl M. and Ides, Allan, "The Unitary Executive.” Los Angeles Lawyer, September 2006; Loyola-LA Legal Studies Paper No. 2006-39 at p.1. Available at SSRN: https://ssrn.com/abstract=943046

${ }^{4}$ As the constitutional interpretation approach of our courts, as developed by the apex court, is to read the provisions of the constitution holistically (together) and not individualistically (in isolation) in order to arrive at the meaning and purport of constitutional provisions. See Abegunde v. Ondo State House of Assembly \& Ors. (2015) All FWLR (Pt. 786) 423; (2015) 8 NWLR (Pt. 1461) 314; (2015) 4-5 SC (Pt. I) 1; A.G Federation v Atiku Abubakar [2007] 8 NWLR 117

${ }^{5}$ (2002) 9 NWLR (Pt. 772) 222; (2002) 6 S.C (Pt. I) 1 per Uwais CJN

${ }^{6}$ Dodo v EFCC [2013] 1 NWLR (Pt. 1336) 468 at 511; Akingbola v FRN [2012] 9 NWLR (Pt. 1306) 511 at 537 per Saulawa JCA

${ }^{7}$ Attorney General Ondo State v Attorney General Federation (supra)
} 
which the country finds itself is largely attributable to the notorious virus which is known as corruption. This court is bound to take judicial notice of these facts and is so invited to do so...' It is from this background that I say that the ruling of the learned trial judge is commendable and it has the effect of sanitizing the polluted and corrupt society. ${ }^{1}$

With regard to the legislative competence of the National Assembly to make laws concerning corruption and abuse of power, the Supreme Court in Attorney-General of Ondo State v. Attorney-General of the Federation \& Ors (2002), ${ }^{2}$ held as follows:

Item 67 under the exclusive legislative list read together with the provisions of section 4 , subsection (2) provide that the National Assembly is empowered to make law for the peace, order and good government of the federation and any part thereof. It follows, therefore, that the National Assembly has the power to legislate against corruption and abuse of office even as it applies to persons not in authority under public or government office. For the aim of making law is to achieve the common good. The power of the National Assembly is not therefore residual under the constitution but might be concurrent with the powers of State House of Assembly and local government council, depending on the interpretation given to the word "state" in section 15 subsection (5) of the constitution ..."

Clearly, the legislature and the executive have different roles in the fight against corruption. One enacts the relevant statutes while the other enforces them. However, the various arms of government have a duty to ensure that effect is given to laws of the land. ${ }^{3}$ Executive power when challenged is examined on three criteria: (a) where the power is derived and based on constitutional provisions, and therefore constitutional; (b) where the power is exercised based on validly enacted enabling statute, and therefore valid; (c) where the power is not derived or based on either the constitution or validly passed enabling statute but of a general concept of executive power based on assumed necessity by the executive, and the therefore liable to successful unconstitutionality and illegality challenge. ${ }^{4}$

Clearly, the Executive Order No. 62018 falls within the first criteria as sections 1 expressly states it to be based on constitutional provisions, as earlier mentioned. The Federal High Court, Abuja on held that Executive Order 6 is in line with the 1999 Constitution. The presiding judge, Hon. Justice Ijeoma Ojukwu, made the pronouncement while delivering judgment in a suit filed by two lawyers; Ikenga Ugochinyere and Kenneth Udeze, challenging the legitimacy of the order. Justice Ojukwu held that it was within the powers of the president, as granted by the constitution, to issue Executive Orders for the execution of policies by the executive arm of government provided such orders respected the principles of separation of powers. She also said that the Executive Order 6 did not violate the right of citizens to own property. According to her, it is rather informed by President's willingness to save suspected property from being dissipated. While insisting that the order was constitutional, Hon. Justice Ojukwu, however, cautioned that the powers given to the Attorney General of the Federation (AGF) under the order must be exercised in accordance with the provisions of the constitution. She further held that although the order seemed to give the AGF discretion as to when to seek permission of the court to seize any suspected property, he must at all times, obtain a court order before seizing any asset. ${ }^{5}$

\subsection{Challenges}

There have been arguments and challenges raised about the constitutionality and legality of the Executive Order that will be identified and fully discussed hereafter, and some of these issues have already been canvassed in cases before the Federal High Court, and verdicts have been given that have shed more light on these challenges.

\subsubsection{Supremacy of the Constitution}

Deriving from the principle of supremacy of the constitution and separation of powers, premised on sections $1(3), 4,5$, and 6 of the Constitution, it is argued that the Executive Order is ultra vires, as the executive powers vested in section 5 can only be exercised subsequent to the law-making powers of the legislature in section 4 of the Constitution, to give delegated powers of rule-making, to the President, for the making of such Executive Order. Deploying the Supreme Court's rationale that by the combined effect of Section 4(2) and item 60(a) Part 1 of the Second Schedule to the Constitution, only the National Assembly can by law, make Section 15 (5) of the Constitution which is part of the Fundamental Objectives and Directive Principles of State Policy justiciable and

\footnotetext{
1 (2008) All FWLR (Pt. 417) 124 at 132 - 133, pp. 151 - 152, paras. C - B (CA) per Omokri JCA (as he then was).

${ }^{2}$ LPELR-623(SC) Per UWAIS J.S.C. (Pp. 54-55, paras. E-A); see also Chief Rasheed Ladoja v. Federal Republic of Nigeria \& Anor (2014) LPELR-22432(CA) per Ikyegh, J.C.A (Pp. 46-47, paras. A-A) on the purpose of anticorruption legislation.

${ }^{3}$ See Oyewo supra note 4 at p.95 (noting the example of section 315(2) of 1999 Constitution (as amended) which enables the appropriate authority to "make such necessary modifications... of any existing law... to bring that law into conformity with the provisions of the Constitution."

${ }^{4}$ Attorney General Lagos State v Attorney-General Federation (2004) 18 NWLR (Pt.904)1; (2004) LPELR-SC.70/2004

5 "Court validates Buhari's Executive Order to seize properties linked to corruption", Premuim Times, October 11, 2018, available at: https://www.premiumtimesng.com/news/headlines/289832-court-validates-buharis-executive-order-to-seize-properties-linked-tocorruption.html
} 
enforceable. This point was articulated clearly by the Supreme Court in Attorney General of Ondo State v. Attorney General of the Federation. ${ }^{1}$ This argument is supported by the definition of law in section 18(1) of the Interpretation Act thus: "Law" means any law enacted or having effect as if enacted by the legislature of a State and includes any instrument having the force of law which is made under a law." However, such narrow construction of the constitution is not supported by the plethora of decisions of the apex court, that lend credence to the position that the constitution can directly enable the President to make Executive Orders pursuant to sections 5, 15(5), 13, 130, and item 60(a) Part I of the Second Schedule. ${ }^{2}$ By nature an Executive Order is a presidential policy directive that implements or interprets a federal statute, a constitutional provision, or a treaty without the requirement of legislative enactment or approval. ${ }^{3}$ Hence, the President can constitutionally exercise its powers under sections 5 and 15(5) to make the Executive Order 6 of 2018.

Another challenge to the Order is based on the doctrine of 'covering the field' as applied by the Supreme Court in INEC $v \mathrm{Musa}^{4}$ arising from section 1(c) of the Executive Order pertaining to section 174 of the Constitution and the powers of the Attorney General of the Federation thereunder. Suffice it to say that this broad attack is inapplicable to directive made by the President pursuant to section 5 to the Attorney General, especially as section 130 and 148 confer power on the President to give such directive to the Attorney General, the President's appointee. ${ }^{5}$

\subsubsection{Fundamental Rights Violations}

Undoubtedly, the procedures for assets recovery, - freezing, seizure, confiscation, forfeiture and repatriation portend potential conflicts and/or violation of the fundamental rights of persons accused of corrupt practices and money laundering, hence, the need for judicial balancing of interests of state and individuals in order to ensure compliance with constitutional safeguards of guaranteed rights and justice. ${ }^{6}$ Indeed, the fundamental human rights of persons who are subject to assets recovery proceedings are to also be balanced against the general right of the victims of corruption and money laundering to development, including: right to education; right to health; right to adequate food; right to due process; right to a healthy environment; and infrastructural development (these soci-economic and cultural rights are, however, non-justiciable under the 1999 Constitution). $^{7}$ The focus of most violation of fundamental rights by the Executive Order are on the: right to fair hearing/trial; presumption of innocence; right to property; and third-party rights. These will now be examined in detail.

(a) Right to Fair hearing/trial

By the provisions of section 36(1), a person is entitled to fair hearing from an independent and impartial court or tribunal within a reasonable time in the determination of his/her civil rights and obligations. ${ }^{8}$ The test for measuring the fairness of the proceedings in a Court of first instance is the impression of any reasonable person who was present at the trial. ${ }^{9}$ When a person who is entitled to be heard is denied a hearing before a decision affecting him is made, then by virtue of section 36(1) of the Constitution, that decision cannot bind him; because he was not given the opportunity of being heard. ${ }^{10}$ The practice of obtaining freezing orders ex parte on reasonable suspicion in pre-conviction, and especially, during investigation and pre-criminal charges proceedings (section 1(c)(iii)(iv) and (v) of the Executive Order 6 2018), have been alleged to violate the principle of fair hearing/trail. However, the ex parte application proceedings are not unconstitutional or in violation of the right to fair hearing/trail, as it is done pursuant to the powers of the courts under section 6 of the 1999 Constitution. Indeed, section 3 of the Executive Order 62018 acknowledges the right to fair hearing/trail of any "person who alleges that his rights have been, is being or are likely to be contravened to apply to a

\footnotetext{
${ }^{1}$ (2002) 9 NWLR (Pt.772) 222. See Inibehe Effiong, Unconstitutional, Null And Void - Legal Opinion On Preservation Of Suspicious Assets Order, ProshareFDN, Sunday, July 08, 2018 08.45AM, available at: http://saharareporters.com/2018/07/09/unconstitutional-null-andvoid-legal-opinion-preservation-suspicious-assets-order-inibehe visited on October 15, 2018

${ }^{2}$ A.-G., Abia v A.-G., Federation [2003] 4 NWLR (PT 809) p. 124 at 177 para. F. ; Owoyemi v Adekoya [2003] 18 NWLR (Pt 852) p 307 at p 336 paras D-H. See Okebukola and Kana, "Executive Orders in Nigeria as Valid Legislative Instruments and Administrative Tools." NAUJILJ Vol. 3 (2012) at p.61.

3 J. Lehman and S. Phelps, West's Encyclopaedia of American Law (Detroit: The Gale Group Inc. 2005) at http://www.encyclopedia.com/law/encyclopedias-almanacs. accessed 15/10/2018; Imo J. Udofa, Presidential Law-making Power in Nigeria and America: Turning Presidents into Supermen? Global Journal of Politics and Law Research Vol.5, No.3, (2017) 1-16 at 10-11

${ }^{4}[2003] 3$ MJSC1

${ }^{5}$ State v Ilori

${ }^{6}$ Kodjo Attisso, The Recovery of Stolen Assets:sep:Seeking to balance fundamental human rights at stake, Working Paper Series No 08 International Centre for Asset Recovery (ICAR) of the Basel Institute on Governance. (2010) pp. 8-13

${ }^{7}$ ibid

${ }^{8}$ CKWM Co. Ltd. v Akingbade [2017] 32 WRN 44 at 62 per Onnoghen JSC (SC); Isyaku Mohammed v. Kano NA (1968) 1 ANLR 424.

${ }^{9}$ Kalu v. State (2017) LPELR-42101(SC); Otapo v Sunmonu and Ors [1987] NWLR (Pt. 58) 587; Obaro v Hassan (2013) LPELR- 20089 (SC) 32-33; E-B; Tunbi v Opawole [2000] 2 NWLR (Pt. 644) 275. The term fair hearing therefore has been defined variously to mean trial conducted according to all legal rules formulated to ensure that justice is done to all parties to the case. See Ogunsanya v. The State (2011) 12 NWLR (pt. 1261) 401 at 434; also in Ugoru v. State (2002) 4 SC (P 11) 13 at 19 U. A. Kalgo, JSC said: "... the term 'fair hearing' in relation to a case in my view, means that trial to the case of the conduct of the proceedings thereof, is in accordance with the relevant law and rules in order to ensure justice and fairness ...Per OGUNBIYI, J.S.C. (pp. 11-12, Paras. F- B) in Nwokocha v. AG of Imo State (2016) LPELR-40077(SC)

${ }^{10}$ Onyekwuluje v Benue State Government [2016] 3 WRN 1 at 27 per Galadima JSC (SC)
} 
competent Court for redress." Clearly, with respect to those matters in the First Schedule, i.e. criminal trials already instituted before courts of competent jurisdiction, such application to vacate, quash or vary an ex parte or interlocutory blocking, freezing, forfeiture or confiscation order, will be to the courts before which such persons have been charged. However, for such orders made at the investigation or pre-criminal charges stage, application to vacate, quash or vary an ex parte or interlocutory blocking, freezing, forfeiture or confiscation order, will be before the court that made the order. ${ }^{1}$ Specifically, in Felimon Enterprises Limited v. Chairman, E.F.C.C. [supra] the Supreme Court, inter alia, held that:

It is not in dispute that there is no provision in the EFCC Act for setting aside of interim orders of attachment, that however cannot be taken as a blanket principle that once the attachment or seizure has been made, it becomes irrevocable. I say so because; firstly, the attachment under the relevant sections, 27, 28, and 29 of the EFCC Act is done upon an ex parte interim order. That is outside the knowledge of the contending party and so when circumstances are thrown up which would impel the court for a re-visit of the order, it behoves the court of trial that made the interim order in the first place to take a second judicial and judicious look at the matter to see whether or not a need for setting aside or refusing to set aside exist .... ${ }^{2}$

Conclusively, it can be stated that a law, or as in the instant discuss - an Order, that affects civil rights and obligations is saved under the fair hearing provisions of section 36 of the 1999 Constitution, if it provides opportunity for the person whose civil rights and obligations is affected to make representations to the administering authority, before that authority makes the decision affecting the person. ${ }^{3}$ Such a law must not also make the decision of the administering authority final and conclusive. ${ }^{4}$ Moreover, the decision of the administering authority must be subject to the due process of the law and judicial review. Thus, in Umezulike $v$. Chairman, EFCC ${ }^{5}$ Ogunwumiju JCA stated the principle succinctly thus:

It is my humble view that in whatever circumstances, whether it is a matter involving criminal prosecution under the EFCC Act or not, an order of attachment of property can be set aside, quashed or vacated where there is proof that there has been suppression of material facts or misrepresentation of facts or where the Court which made the order had no jurisdiction to make the order.

The right to a fair hearing of the person adversely affected by the exercise of power pursuant to Order No. 6 of 2018, subsequent to an ex parte order made to affect his/her assets, bank accounts, and other properties, can be secured through application to vacate, quash or vary an ex parte or interlocutory blocking, freezing, forfeiture or confiscation order. The question of entitlement to damages through a fundamental rights infringement action in the event of a wrongful exercise of power under Order No. 6 of 2018, ought to be resolved by the court in favour of the victim as a counterpoise against any form of abuse of the powers thereunder.

Moreover, where ex parte order is obtained without further investigation or prosecution, then the court ought to vacate such order after a reasonable time has lapsed. In Skye Bank Plc v. Okene A. David \& Ors. 6 the Court of Appeal warned against the perpetuity of ex-parte orders freezing bank accounts obtained by the EFCC. The Court of Appeal held thus:

...I do not think that the law intended to create a monster out of the EFCC, to just, at the slightest suspicion, whether real or imagined, cause the court to freeze an account by ex parte order, indefinitely, without bringing the operator of the account to trial and giving him the opportunity to be heard on why the account is frozen. There is nothing in this case to show that after obtaining the ex-parte order on 29/1/2010, that the 21st and 22nd Respondents were arraigned for trial for any offence, or that there was any Motion on Notice, served on the 21 st and 22nd Respondents for any hearing of any complaint relating to the freezing of the accounts by the E.F.C.C. I have already stated why it will be extremely dangerous to allow such abuse of ex-parte orders. I therefore see nothing amiss in the decision of the learned trial court in holding that such ex-parte order had run its full course and had lapsed. Order 26 Rule 12(1)(2) of the Federal High Court...

The Courts must be vigilante to ensure that the constitutionally guaranteed right of citizens to fair hearing/trial are not trampled upon in the operation of Order No. 6 of 2018.

\footnotetext{
${ }^{1}$ Felimon Enterprises Limited v. Chairman, E.F.C.C. [2018] 7 NWLR (Pt 1617) 56 at 67, paras D-F, for the simple and logical reason that an interim freezing order, being a discretionary order obtained ex-parte to preserve the subject of litigation pending a hearing on notice, can be discharged by the court that made it.

${ }^{2}$ See also Umezulike v. Chairman EFCC [2017] LPELR-43454(CA)

${ }^{3}$ Section 36(2)(a) of the Constitution. Okoye v COP [2016] 29 WRN 134 at 152 per Aka'ahs JSC (SC)

${ }^{4}$ Section 36(2)(b) of the Constitution. Skye Bank v Iwu [2018] 6 WRN 1 at 111-112 per Peter-Odili JSC (SC)

${ }^{5}$ (2017) LPELR-43454(CA). In U.T.B. Ltd \& Ors v. Dolmesch Pharmacy Nig. Ltd [2007] 16 NWLR (Pt. 1061) 520 at 542 Para. D, the Supreme Court held that an order of injunction obtained ex-parte may be set aside, inter alia, if the order was irregularly granted or was procured by misrepresentation or suppression of material facts.

${ }^{6}$ (2014) LPELR-23731(CA)
} 
(b) Presumption of Innocence

Every person charged with a criminal offence is to be presumed innocent until proved guilty by a court of competent jurisdiction. ${ }^{1}$ Provided that a law may impose upon a person the burden of proving particular facts. ${ }^{2}$ It has been observed that conflicts between the recovery of stolen assets proceedings under the Executive Order 6 and the principle of the presumption of innocence may arise in two situations:

1. if the decision on confiscation precedes even the conviction of the perpetrator of the crime, and if it is based on the argument of guilt;

2. if the burden of proof is not met

The confiscation of assets before the conviction of those holding them may violate the principle of the presumption of innocence in that it rests on the anticipation of the person's guilt. It assumes without establishing guilt that the accused committed a crime. ${ }^{3}$ The principle of the presumption of innocence encompasses, among other elements, the burden of proof being upon the prosecution, the accused being protected against selfincrimination and the accused having the right to remain silent, the prosecution of the offence should not commence from a construct of assumption of guilt. ${ }^{4}$

However, the proviso to section 36(5) of the 1999 Constitution on presumption of innocence definitely allows for such shift in the presumption thus: "Provided that nothing in this section shall invalidate any law by reason only that the law imposes upon any such person the burden of proving particular facts." 5 The Court of Appeal in Dame Mrs Patience Ibifaka Jonathan v Federal Republic of Nigeria held that the presumption of innocence does not come into play in a non-conviction based civil-forfeiture proceeding. ${ }^{6}$ Civil forfeiture entails an in rem action, that is, an action against the asset itself and not against the individual. It is an action distinct from the criminal proceedings and is filed before, during or after forfeiture, does not depend on a criminal conviction. The state is required to show that the asset in question is tainted, either because it is the proceeds or an instrumentality of corruption. In contrast to criminal forfeiture, the standard of proof in civil forfeiture is proof on a balance of probabilities or preponderance of the evidence. ${ }^{7}$ The law ascribes "to the property a certain personality, a power of becomes a third party and he is required to show that the property is "innocent" 8 . Civil forfeiture actions, unlike criminal forfeiture actions, can be brought against any property which is either the proceeds of or derived from a course of corrupt conduct. In other words, it is not limited to property related to a particular transaction. While criminal forfeiture does not affect property held by third parties, civil forfeiture can forfeit the property of a third party who has no bona fide defence. Thus, once the state shows that the asset is tainted and proper notice of the forfeiture has been given to all interested parties, an order of forfeiture may be issued regardless of who the owner of the property might be. ${ }^{9}$ Hence, the issue of presumption of innocence in such civil proceeding becomes moot.

A learned colleague made a revealing observation on presumption of innocence and corruption cases thus:

In the premise, the presumption of innocent if strictly adhered to will undoubtedly confer undue protection on offenders and expose the administration of justice to ridicule in cases involving corruption and corrupt practices by public office holders and public officers. Furthermore, in order to deter other potential offenders and inculcate a sense of accountability in public office holders, it is necessary to shift the burden of proof in such criminal cases to the accused persons.

Political and public office holders occupy positions of trust vis-à-vis, the management of the wealth of

\footnotetext{
${ }^{1}$ Salami v Commissioner of Police (2009) All FWLR (pt495) 1765; (2009) All FWLR (pt450) 722; Laoye v The State (1995) 1 NWLR (Pt 10) 832 .

${ }^{2}$ Proviso to s. 36(5) of the Constitution; Alabi v. State (1987) 7 NWLR (Pt. 307) 571.

${ }^{3}$ Kodjo Attisso, The Recovery of Stolen Assets:sEp:Seeking to balance fundamental human rights at stake, Working Paper Series No 08 International Centre for Asset Recovery (ICAR) of the Basel Institute on Governance. (2010) pp. 11-12; Tom Kabau, "Constitutional Dilemmas in the Recovery of Corruptly Acquired Assets in Kenya: Strengthening Judicial Assault on Corruption" Africa Journal of Comparative Constitutional Law, Vol. 1 (2016), 1

${ }^{4}$ Section 36 of the 1999 Constitution (as amended)

${ }^{5}$ (italics mine) Alabi v. State (1987) 7 NWLR (Pt. 307) 571. See Jacob Abiodun Dada, and Eugene A. Opara, is i Application of Presumption of Innocence in Nigeria: Bedrock of Justice or Refuge for Felons, Journal of Law, Policy and Globalizationisepi:Vol.28, 2014, 68-77

${ }^{6}$ Dame Mrs Patience Ibifaka Jonathan v Federal Republic of Nigeria, LER [2018] CA/L/578/2017 per Owoade JCA: "On presumption of innocence, I must say that the Appellant in the instant case was never on trial for a criminal offence, therefore the doctrine of presumption of innocence is not applicable to the circumstances of the case. The issue of innocence of the Appellant does not come into play in a nonconviction based forfeiture proceeding."

${ }^{7}$ Greenberg T.S et al, Stolen Asset Recovery: A Good Practices Guide for Non- Conviction Based Asset Forfeiture. Washington D.C, (2009) pp. 14 - 15. The International Bank for Reconstruction and Development/World Bank. Civil forfeiture is applied often in situations where criminal forfeiture is impossible or unavailable. These include situations: (i)where the offender is absent by reason of death or flight; (ii)where prosecution is impossible because of the powerful influence of the offender or because the offender enjoys immunity from prosecution; (iii) where the property is held by a third party who has not been charged with a criminal offence but is aware or wilfully blind to the fact that the property stems from an act of corruption; (iv) where there is insufficient evidence to sustain the charges against the offender.

${ }^{8}$ US v One 6.5mm Mainlicher-Carcaro military rifle, 250 F.Supp. 410 (N.D Tx.1966). In that case, the court ordered the forfeiture of the rifle used in assassinating President John. F. Kennedy.

${ }^{9}$ Greenberg T.S. ibid
} 
the nation. There is therefore, every reason to support a legislation that seeks to make them accountable as trustees in the management of the Nation's wealth. A nation plagued by corruption, abuse of office and white-collar crimes, deserves a more result-oriented legislation which seeks to combat the commission of these offences and ensure the economic survival of the nation. ${ }^{1}$

In Jonathan $v F R N^{2}$ the Court of Appeal held the provisions of section 17 of Advance Fee Fraud Act 2006 to be constitutional and the challenge of the provisions being in violation of presumption of innocence under section 36(5) was unsuccessful.

Based on section 36(5), in criminal prosecution the presumption of innocence of the accused will not be deemed to have been violated merely because the burden of proof shifts to the person upon tendering of credible evidence that implicates corruption. In Dauda $v F R N^{3}$ the Supreme Court affirmed that under the Money Laundering Act and corruption cases, ${ }^{4}$ the Defendant has to establish the legitimacy of illicit money found in his possession. The presumption of innocence still prevails as the prosecution must prove its case beyond reasonable doubt irrespective of section 36(5).

(c) Right to Property

There is a general constitutional prohibition of government from compulsorily acquiring movable and immovable property in the Constitution, ${ }^{5}$ as was recognized by the Court of Appeal in Adu v. Lagos State Task Force on Environment and Special Offences Unit. ${ }^{6}$ It is not as if property cannot be compulsorily acquired by the government under any circumstances. What the Constitution requires is that such compulsory acquisition must be in a manner and for purposes prescribed by law. ${ }^{7}$ The government with all its might cannot acquire the land of an individual without paying adequate compensation. That is, compulsory acquisition is not to be at the whims and caprices of anybody or authority. ${ }^{8}$ Additionally, for such acquisition to pass constitutional muster, there must be prompt payment of compensation for the property acquired. ${ }^{9}$ The person whose property is compulsorily acquired is also to be given access to a court having jurisdiction of the subject-matter for the determination of his/her interest in the property and to challenge amount of compensation paid. ${ }^{10}$

The seizure and confiscation of stolen assets under Executive Order No. 6 will deprive individuals temporarily or permanently of their right to their property. This gives rise to a number of concerns in that the constitution protect and guarantee the right of individual ownership. In principle, no one may be arbitrarily deprived of his/her right to property. Normal proceedings for the recovery of diverted funds take place in four stages: location of the assets, freezing and seizure, final confiscation, and then restitution of the assets to the lawful owners. It is the confiscation that presents the greatest threat to a person's right to his/her property. Thus, in EFCC v. Thomas ${ }^{11}$ money seized by EFCC at a domestic Airport was held to be ultra vires the powers of EFCC as the right to legitimately own money in cash guaranteed under section 44 has not in any way been abrogated by the anti-corruption legal framework. Although, the right to own money and other valuable properties is acknowledged to be limited under section $44(2) .12$

There are exemptions under section 44(2) of the 1999 Constitution that the courts have held to be permissible interference with the guaranteed right to property under section 44(1) by the anti-corruption legislations that the Attorney-General will be relying on under the Executive Order No. 6 of 2018. In Dame Mrs. Patience Ibifaka Jonathan vs Federal Republic of Nigeria ${ }^{13}$ where the wife of the former President of Nigeria was challenging the investigation by the EFCC and the interim forfeiture orders made by the trial court in relation to huge sums of money in bank accounts reasonable suspected to be proceeds of unlawful activities, the Court of Appeal, per Owoade JCA, held that, the provision of Section 44 (2) (b) of the Constitution provides a disjunctive or in between the words "whether under civil Process" AND "after conviction for an offence". Clearly, therefore it is not only "after conviction for an offence" could a citizen's property be forfeited especially in the case of a temporary forfeiture as in the instant case which is clearly covered under Section $44(2)(\mathrm{k})$ of the

\footnotetext{
${ }^{1}$ T. Osipitan, Administration of Criminal Justice: Fair Trial, Presumption of Innocence and the Special Military Tribunals' in Omotota \& Adigun eds, cited in Akinseye-George, Legal System, Corruption and Governance in Nigeria, Lagos: New Century Law Publishers, 2000, at 58-59.

2 (2018) LPELR-43505(CA)

3 (2018) LPELR-43637 (SC)

${ }^{4}$ Based on existing laws contained in section 20(2) of the Money Laundering Act; section 19(5)of the EFCC Act; section 319A of the Penal Code; section 132 and 136 of the Evidence Act, among others.

${ }^{5}$ Section 44 of the Constitution.

${ }^{6}$ (2016) LPELR-40060(CA)

7 Section 44(1) of the Constitution. Aigoro v. Commissioner of Lands and Housing, Kwara State (2011) LPELR-9112(CA); Okon v. Enyiefem (2016) LPELR-41168(CA)

${ }^{8}$ Kukoyi v. Adesina (1999) 10 NWLR (Pt. 624) 63

${ }^{9}$ Section 44(1)(a) of the Constitution. COP v. Ibrahim (2016) LPELR-41319(CA) per Akeju JCA at pp. 11-13

${ }^{10}$ Section 44(1)(b) of the Constitution. ELF Petroleum v. Umah (2018) LPELR-43600(SC); for the Court of Appeal judgment of $13^{\text {th }}$ July 2006 (unreported) available at: https://www.yusufali.net/reports/elf_v_umah.pdf

${ }^{11}$ (2018) LPELR-45547(CA)

${ }^{12}$ Atoyebi v FRN (2017) LPELR-43831(SC); Udeogu v FRN (2016)LPELR-40102(SC)

${ }^{13}$ LER [2018] CA/L/578/2017
} 
1999 Constitution. In particular, the provision of Section $44(2)(\mathrm{k})$ of the 1999 Constitution creates an exception to the general right given to citizens to own movable and immovable properties.

(d) Third-Party Rights

The proceedings and decision taken pursuant to the Executive Order 62018 on freezing, forfeiture, or confiscation will impact items of property in dispute, and thus the right to own property, as has been shown earlier above. In a case in which a third party acquired these in good faith, the decision to freeze, forfeit or confiscate may impact their rights as well. Consequently, the Executive Order 62018 should not extend such measures as forfeiture or confiscation to third-party acquirers who acted in good faith.

On the other hand, forfeiture or confiscation could justifiably be applied against a third party in possession of the asset, if it has been established that the latter was complicit in the crime or was aware that the asset is a proceed of a crime. ${ }^{1}$ In any case, measures directed at third parties must guarantee their basic rights (right to a defense, right to be heard, as well as the right to appeal a conviction). ${ }^{2}$

\subsubsection{Operational Abuse of Power}

The most vociferous attack on the Executive Order No. 6 of 2018 is on its operation by the Attorney General and the anti-corruption agencies and authorities. First, is the allegation of selective justice by the administration in the application of the Order and other anti-corruption legislations to victimise the opposition, and to ignore corrupt practices by party members of the ruling government. Second, is the allegation of abuse by the operators to blackmail and extort bribes and illicit payments in order to have measures and proceedings "neutralised". Third, is the deliberate poor record keeping and account of recovered assets.

Generally, there are legal standards for the exercise of discretionary powers vested in governmental authorities including those conferred under the Executive Order No. 6 of 2018 and the anti-corruption laws on which it is premised. For the exercise of discretion, regard must be had to the rights of all parties while considering what is equitable in all circumstances. In the case of Chief D.A. Eboreime v. BS Arumeme, ${ }^{3}$ the court of Appeal held the following:

Persons who are appointed members of public boards or bodies whose sphere of activities and modus operandi are defined or regulated by statutes ought to always remember that however they feel about any issue that comes before them by virtue of such an appointment, they are bound to act strictly in accordance with the letters of the statutes: where the statutes give them any discretion, it ought to be exercised truly, fairly and reasonably and in such a way that their exercise of the discretion does not run counter to the general law of the land. Anything short of this is an abuse of public power and authority and such an abuse does nobody any good"

Further in the case of Rana Industries v. EFCC $C^{4}$ the Honourable Court discharged a freezing order earlier obtained by the EFCC noting that the commission acted irrationally and did not exercise its discretion properly. With regard to judicial discretion the Court of Appeal in EFCC v. Akingbola (CA/L/462/2011), held as follows:

Yes, it is empowered to exercise its discretion in certain circumstances but it goes without saying that discretion cannot dictate to the law; it is the law that dictates when a court can exercise its discretion; how it can exercise that discretion; and what it is allowed to exercise its discretion on. See UBA V. Stahibau GMBH \& Co. K.G. (1989) 3 NWLR (Pt. 110) 374 where Oputa JCA (as he then was) in dealing with judicial discretion, observed as follows - "Discretion is thus not an indulgence of a judicial whim, but the exercise of judicial judgement based on facts and guided by the law or the equitable decision."

Where such allegations of abuse of power are reasonably supported by proof the court must quash all actions taken pursuant thereto, and order the administration to take legal actions to deal with such abuse..$^{5}$

\subsection{Asset Tracing and Recovery}

The theft of public assets is a development problem of the greatest magnitude. The exact value of state assets that have been stolen from developing countries, including Nigeria, is impossible to determine with any precision. Between $\$ 1$ trillion and $\$ 1.6$ trillion is lost each year to various illegal activities.5 Corrupt public officials in developing and transition countries loot as much as $\$ 40$ billion each year, concealing these funds overseas where they are extremely difficult to recover. ${ }^{6}$ Asset recovery is the process whereby the proceeds of corruption are traced, frozen, confiscated and repatriated in favour of countries that become victims to

${ }^{2}$ Kodjo Attisso, The Recovery of Stolen Assets:s ispes Seeking to balance fundamental human rights at stake, Working Paper Series No 08 International Centre for Asset Recovery (ICAR) of the Basel Institute on Governance. (2010) pp. 11-12

${ }^{3}$ (1977) LPELR-FCA/B/21/77, per Nnaemeka-Agu J.C.A. (pp. 34-35, paras. E-A)

${ }^{4} \mathrm{FHC} / \mathrm{LCS} / 715 / 2015$,

${ }^{5}$ EFCC v. Diamond Bank Plc (2018) LPELR -44217(SC) per Sidi Bage JSC P 23 para A-D and pp. 25-26. Abdulkarim A Kana, Perspectives and Limits of Judicial Discretion in Nigerian Courts, Journal of Law, Policy and Globalisation, Vol. 29, 2014,157 - 167

${ }^{6}$ Theodore S. Greenberg Linda M. Samuel Wingate Grant Larissa Gray, Stolen Asset Recovery: A Good Practices Guide for Non-Conviction Based Asset Forfeiture, 2009, World Bank, pp. 7-8
} 
corruption. Asset recovery is an effective countermeasure to corruption because it signalises to corrupt leaders that corruption no longer pays. However, many developing countries still lack the skills to collect evidence, prepare indictments, adjudicate cases and obtain convictions. Asset recovery is a complex and multi-faceted process which involves several steps that require high levels of technical knowledge and capacity. The actual repatriation of assets stands at the very end of a series of actions. ${ }^{1}$

Asset recovery in corruption cases includes the uncovering of corruption and the tracing, freezing, confiscating and returning of funds obtained through corrupt activities. The asset recovery process involves four steps: (1) identification; (2) investigation, tracing, freezing and seizing; (3) confiscation or forfeiture; and (4) return of the stolen assets to the owner. The legal mechanisms for assets recovery are: (a) criminal or conviction based asset(s) forfeiture; and (b) civil or non-conviction based asset(s) forfeiture.

In 2017, the Presidential Advisory Committee Against Corruption in collaboration with the Ministry of Justice and Foreign Affairs held a conference on Promoting International Co-operation in Combatting Illicit Financial Flows and Enhancing Asset Recovery to Foster Sustainable Development, that produced the Abuja Declaration on Illicit Financial Flow (IFF) and Asset Recovery. The Executive Order 6 2018, can therefore be seen as an executive directive to the Attorney General and all anti-corruption agencies and authorities for an integrated and harmonized approach to combating IFF and asset recovery. The Order operates within the existing legal framework that includes: the Constitution of the Federal Republic of Nigeria, 1999 (as amended); The Criminal Code Act, 1961; Penal Code Law, 1959; Administration of Criminal Justice Act; Corrupt Practices and Other Related Offences Act, 2003; Independent Corrupt Practices and Other Related Offences Commission; Economic and Financial Crimes (Establishment) Act, 2004; Money Laundering (Prohibition) Act, 2004; Advance Fee Fraud Act 2006; inter alia. The domestic legal framework is complimented by an international legal framework that also include: United Nations Convention Against Corruption (UNCAC) of 2005; African Union Convention on Preventing and Combating Corruption and Related Offences (AU Convention) of 2003; Economic Community of West African Protocol on the Fight Against Corruption (ECOWAS Protocol) of 2001; United Nations Convention Against Transnational Organised Crime (UNTOC) of 2003.

Clearly, the case law already developed by the courts on these legal regimes will aid in the interpretation and application of the provisions of the Order. The question therefore is what is the impact of the Order on Assets recovery.

\subsection{Impact of Presidential Executive Order No. 6 (2018) on Government's Efforts on Asset Recovery}

From a cursory look the likely impact of the Presidential Executive Order No. 6 (2018) can be summarized as follows:

- Prevention of the dissipation of assets within Nigeria suspected to be proceeds of a crime under applicable laws.

- Synergy in the investigation and prosecution of offenders through the coordination of the Attorney-General of the Federation subject to section 174 of the CFRN.

- Synchronises the legal regimes and personnel for the effective enforcement of the anti-corruption legal regime in Nigeria

- Energise the corruption cases already filed against persons listed in the First Schedule

- Section 5(b)(i) of the executive order sets the threshold value of assets coming under the purview of this order at $\$ 50,000,000.00$. This streamlines the number of cases for easy coordination.

- As corruption is multifaceted, this Executive Order brings together twenty government agencies in order to effectively monitor and coordinate their activities.

- An effective sanction and deterrent to corrupt public office holders and their agents, as they will be deprived of the loot of their corrupt practices

- Aids in international cooperation for the repatriation of stolen wealth of the Nigerian nation

\subsection{Conclusion}

The Executive Order No. 6 2018, can be seen as an executive directive purposively intended for the furtherance of the anti-corruption governmental policy of the President Buhari Administration, to not only infuse life into the seemingly waning anti-corruption campaign, but also to serve as an instrument and weapon of effectively combating corruption in Nigeria. Obviously, constitutional and legal challenges will be raised as to the validity of the Order, however, the drafters of the Order borrowed from the existing corpus juris to neutralise the potency of such challenges, as the case law on the anti-corruption laws in relation to the constitution will validate the Order's constitutionality and legality.

It is hoped that the Order will not be abused in its operation as the clear objectives of the Order are patently in the best interest of the citizens and for the sustainable development of the country.

\footnotetext{
${ }^{1}$ Capacity Building in Asset Recovery, 2011 Basel Institute on Governance, International Centre for Asset Recovery, pp 3-9
} 